\title{
Phytochemical Evaluation and Antibacterial Activity of Fruit Extract of Solanum surattense Burm F. against Some Pathogenic Bacteria
}

\author{
Dhanalakshmi $\mathbf{R}^{\star}$, Jaffarlqbal J, Nausath Jabeen K, \\ Noorul Zaithun Hidhaya M, Meena K, Tamizharasan
}

Edayathangudy G.S. Pillay College of Pharmacy, Nagapattinam, Tamil Nadu, India

\begin{abstract}
The objective of this study was to evaluate phytochemical constituents and antibacterial activity of hydroalcoholic extract of Solanum surattense fruit against some grampositive and gram-negative bacterial strains. The evaluation of antibacterial activity was carried out by using the disc diffusion method, determination of minimum inhibitory concentration (MIC) and minimum bactericidal concentration (MBC). Ciprofloxacin was used as positive control. Hydroalcoholic extract of Solanum surattense fruit containing alkaloids, flavonoids, phenol, saponins, terpenoids, glycosides, sterols, proteins and tannins. Efficacy data analysis showed that hydroalcoholic extracts of fruit of Solanum surattense $(1 \mathrm{mg} / \mathrm{ml})$ inhibited the growth of Staphylococcus aureus, Bacillus subtilis, Escherichia coli and Salmonella typhi with mean diameters of inhibition zones being 24, 25, 28 and $30 \mathrm{~mm}$ respectively. On the other hand, minimum inhibitory concentration and minimum bactericidal concentration value of 0.062 and $0.25 \mathrm{mg} / \mathrm{ml}, 0.062$ and $0.25 \mathrm{mg} / \mathrm{ml}, 0.312$ and $0.125 \mathrm{mg} / \mathrm{ml}, 0.156$ and $0.0312 \mathrm{mg} / \mathrm{ml}$ were recorded against Staphylococcus aureus, Bacillus subtilis, Escherichia coli and Salmonella typhi respectively. Hydroalcoholic extracts of Solanum surattense fruit have potent antibacterial activity against the different tested bacterial strains. This activity supports their use in treatment of infections caused by such resistant bacteria.
\end{abstract}

Key words : Solanum surattense, phytochemical analysis, antibacterial activity, Inhibition zones, MIC and MBC.

\section{Introduction}

For ages nature has gifted us plenty of herbs and plants which form the main source of traditional medicines used to help in relief from illness and are still widely used all over the world ${ }^{1}$. Medicinal plants have been used for centuries as remedies for human diseases as they contain components of therapeutic value. There are numerous plant natural products which have antifungal, antibacterial and antiprotozoal activities that could be used either systemically or locally ${ }^{2}$. Since earliest times, many plants have been known to exert healing properties against human infections due to their content of secondary metabolites, which in more recent times have been found to act as antimicrobial agents against human pathogens ${ }^{3}$. Antibiotics are undeniably one of the 
most important therapeutic discoveries of the 20th century that had effectiveness against serious bacterial infections. However, only one third of the infectious diseases known have been treated from these synthetic products ${ }^{4}$. Antibiotic resistance has become a serious and widespread problem in developing countries, both in hospitals and the community, causing high mortality each year ${ }^{5}$. One of the methods to reduce the resistance to antibiotics is by using antibiotic resistance inhibitors from plants ${ }^{6,7}$. Nevertheless, the discovery of new antibiotics is very expensive and time consuming, requiring about ten years to bring a new antibiotic to market. Therefore, the search for antibacterial substances derived from natural products, such as phytochemicals, has gained increasing importance alongside the discovery of new synthetic chemical compounds with antibiotic properties $^{8}$. Solanum surattense (Solanaceae) is frequently used in indian traditional medicine for curing various ailments such as respiratory diseases, gonorrhoea, rheumatism, fever and asthma ${ }^{9}$. Solanums urattense is widely spread throughout india in dry situation as abundant by road sides and wastelands. It is essentially a warm season crop grown mainly in tropical and sub-tropical regions ${ }^{10}$. The plant is useful in fever, cough, asthma and pain in chest, being used in the formof decoction or electuary.The fruit and leaf extract possess significant antihyperglycemic activity ${ }^{11,12,13}$. The aim of this study was to screen the invitro antibacterial activity of hydroalcoholic extract of fruit of Solanum surattense against some Gram-positive and Gram-negative bacterial strains.

\section{Material and Methods}

\section{Collection and identification of plants materials:}

The fruits of Solanum surattense were used for the study. It was collected from Tiruvarur district,Tamil nadu during the month of March and April. The plant materials were taxonomically identified and authenticated by Dr.S. JOHN BRITTO., Director, The Rapinat Herbarium Centre for Molecular Systematic, St. Joseph's college (campus) Tiruchirappalli-620 002, Tamil Nadu,India. The plant was thoroughly washed in running tap water to remove soil particles and adhered debris and finally washed with distilled water. The fruits of the plant alone were segregated and dried under shade, pulverized by a mechanical grinder into fine powder. The powdered materials were stored in air tight polythene bags till use.

\section{Preparation of extracts:}

The powdered plant materials of Solanum surattense fruits were subjected to hydroalcoholic extraction in the ratio of water: ethanol as 30:70. The extraction was done by hot continuous percolation method in Soxhlet apparatus for $24 \mathrm{hrs}$. The extract was concentrated by using a rotary evaporator till dry powder was obtained.

\section{Percentage yield for the hydroalcoholic extract of Solanum surattense fruits}

The percentage yield for the hydroalcoholic extract of fruits of Solanum surattense was calculated with reference to air dried powdertaken using the formula given below.

$$
\text { Percentage yield }=\frac{\text { Weight in grams of extracts obtained }}{\text { Weight in grams of plant materials taken }} \times 100
$$

\section{Preliminary phytochemical screening:}

Preliminary phytochemical screening was conducted on hydroalcoholic extract of fruits of Solanum surattense to determine the different phytochemical constituents present in the extracts ${ }^{14}$.

Thin-layer Chromatographic Studies (TLC) ${ }^{15}$ :

Thin-layer chromatography was carried out on hydroalcoholic extract of fruits of Solanum surattense using a sheet of aluminium foil which is coated with a thin layer of adsorbent silica gel, which are commercially available 60 F254 (Merck). The plates were cut with scissorsand marked with pencil about $2 \mathrm{~cm}$ from thebottom of the plate. TLC is performed on Samples prepared with different solvents were spotted onto the TLC plate as a single spot with capillary tubes. TLC plates were viewed in UV chamber at both $254 \mathrm{~nm}$ and $365 \mathrm{~nm}$. The movement of the analyse was expressed by its retention factor (Rf). 
Rf value $=$

Distance travelled by solvent

\section{Anti-bacterial activity of Solanum surattense fruit extracts}

\section{Bacterial strains}

The antibacterial potency of plant extract was evaluatedusingfour bacterial strains. Two strains of Gram-positive bacteria (Staphylococcus aureus and Bacillus subtilis) and two strains of Gram-negative bacteria (Escherichia coli and Salmonella typhi). These microorganisms were collected from CSIR-National Chemical Laboratory, Dr.Homi BhabhaRoad,Pune- 411 008, India.

\section{Inoculums preparation:}

Each bacterial strain was sub cultured overnight at $35^{\circ} \mathrm{C}$ in Mueller-Hilton agar slants. The bacterial growth was harvestedusing $5 \mathrm{ml}$ of sterile saline water; its absorbance was adjusted at $580 \mathrm{~nm}$ and diluted to attain viable cell count of $10^{7} \mathrm{CFU} / \mathrm{ml}$ using spectrophotometer.

\section{A. Disk diffusion method ${ }^{16}$ :}

The disk diffusion method is used to evaluate antimicrobialactivity of the plant extract. The plant extract residues $(1 \mathrm{mg})$ were re-dissolved in $0.5 \%$ DMSO ( $5 \mathrm{ml}$ DMSO make up to $100 \mathrm{ml}$ with water), sterilized throughMillipore filter $(0.22 \mu \mathrm{m})$ then loaded over sterile filter paper discs $(8 \mathrm{~mm}$ in diameter $)$ to obtain final concentration of $1 \mathrm{mg} / \mathrm{ml}$.Ten $\mathrm{ml}$ of Mueller-Hilton agar medium was poured into sterilePetri dishes (as a basal layer) followed with $15 \mathrm{ml}$ of seeded mediumpreviously inoculated with bacterial suspension to attain $10^{7} \mathrm{CFU} / \mathrm{ml}$ of medium. Sterilefilter paper discs loaded with plant extract concentration of $(1 \mathrm{mg} / \mathrm{ml})$ were placed on the top of Mueller-Hilton agar plates.Filter paper discs loaded with $30 \mu \mathrm{g}$ of ciprofloxacin was used as positivecontrol. The plates were kept in the fridge at $5{ }^{\circ} \mathrm{C}$ for $2 \mathrm{~h}$. topermit plant extracts diffusion then incubated at $35{ }^{\circ} \mathrm{C}$ for $24 \mathrm{~h}$. The presence of inhibition zones was measured by Verniercalliper recorded and considered as indication for antibacterial activity.

\section{B. Determination of MIC and MBC values ${ }^{17}$ :}

Using aseptic techniques, a single colony was transferred into a $100 \mathrm{~mL}$ bottle of isosensitest broth capped and placed in incubator overnight at $35^{\circ} \mathrm{C}$. After $12-18 \mathrm{~h}$ ofincubation, using aseptic preparation and the aid of a centrifuge, a clean sample of bacteria was prepared. The brothwas spun down using a centrifuge set at $4000 \mathrm{rpm}$ for 5 minwith appropriate aseptic precautions. The supernatant was discarded into an appropriately labelled contaminated waste beaker. The pellet was resuspended using $20 \mathrm{~mL}$ of sterile normal saline and centrifuged again at $4000 \mathrm{rpm}$ for5min. This step was repeated until the supernatant wasclear. The pellet was then suspended in $20 \mathrm{~mL}$ of sterile normalsaline, and was labelled as Bs. The optical density of the Bs was recorded at $500 \mathrm{~nm}$, and serial dilutions werecarried out with appropriate aseptic techniques until theoptical density was in the range of $0.5-1.0$. The actual numberof colony-forming units was calculated from the viabilitygraph. The dilution factor needed was calculated andthe dilution was carried out to obtain a concentration of $5 \times 10^{6} \mathrm{CFU} / \mathrm{mL}$

\section{Preparation of resazurin solution}

The resazurin solution was prepared by dissolving a270mg tablet in $40 \mathrm{~mL}$ of sterile distilled water. A vortexmixer was used to ensure that it was a well-dissolved andhomogenous solution.

\section{Preparation of Microtitre plates}

Microtitre plates were prepared under aseptic conditions. A germ-free 96 well plate was labelled. First row of the plate was poured with test materials $(100 \mu \mathrm{l})$ in $10 \%(\mathrm{v} / \mathrm{v})$ DMSO or sterile water. Remaining all wells were poured with $50 \mu \mathrm{L}$ ofnutrient broth or normal saline.To each well $10 \mu \mathrm{L}$ of resazurin indicator 
solution was added. $30 \mu \mathrm{l}$ of $3.3 \mathrm{x}$ strength isosensitised broth was added individually to each well to ensure that the final volume was single strength of the nutrient broth. Finally, $10 \mu \mathrm{L}$ of bacterial suspension $(5 \times 106$ $\mathrm{CFU} / \mathrm{mL}$ ) was added to each well to attain a concentration of $5 \times 106 \mathrm{CFU} / \mathrm{mL}$. All plates were incubated at 37 ${ }^{\circ} \mathrm{C}$ for 18-24 h. Colour changes from purple to pink or colourless was noted. MIC Value were recorded from the lowest concentration at which colour changes. Different concentration of sample solution was streaked in petridish containing nutrient broth and incubated at $35^{\circ} \mathrm{C}$ for $24 \mathrm{~h}$. Lowest concentration that gave no visible growth was recorded as minimum bactericidal concentration (MBC).

\section{Results}

\section{Percentage yield}

The percentage yield for the hydroalcoholic extract of Solanum surattense fruit was calculated. Percentage yield was found to be $11.66 \% \mathrm{w} / \mathrm{w}$

\section{Preliminary phytochemical screening}

Preliminary phytochemical screening for the hydroalcoholic extract of Solanum surattense fruit was carried out and the results are tabulated in Table. 1. The hydroalcoholic extract of Solanum surattense fruit containing alkaloids, flavonoids, phenol, saponins, terpenoids, glycosides, sterols, proteins and tannins.

Table 1: Phytochemical constituents of Solanum surattense fruit extract

\begin{tabular}{|l|l|l|}
\hline S. No & Phytochemical constituents & Results \\
\hline 1 & Alkaloids & $(+)$ \\
\hline 2 & Flavonoids & $(+)$ \\
\hline 3 & Phenol & $(+)$ \\
\hline 4 & Saponins & $(+)$ \\
\hline 5 & Terpenoids & $(+)$ \\
\hline 6 & Glycosides & $(+)$ \\
\hline 7 & Sterols & $(+)$ \\
\hline 8 & Proteins & $(+)$ \\
\hline 9 & Tannins & $(+)$ \\
\hline
\end{tabular}

$(+)=$ Present; $(-)=$ absent

\section{Thin layer chromatography}

The results of thin layer chromatographyprofiling are summarized in Table 2and illustrated in Fig2a 2e. TLC Profiling of hydroalcoholic extract of Solanum surattense fruit in different solventsystem confirms the presence of diverse group ofphytochemicals.

Table 2: Rf values for various phytochemicals in Solanum surattense fruit extract

\begin{tabular}{|l|l|l|l|}
\hline S. No & Phytochemical & Solvent system & Rf value \\
\hline 1 & Alkaloids & n-butanol: acetic acid: water $(4: 1: 3)$ & 0.3846 \\
\hline 2 & Glycosides & Toluene: n-butanol $(4: 1)$ & 0.6 \\
\hline 3 & Flavonoids & $\begin{array}{l}\text { Ethyl acetate: Formic acid: acetic acid: water } \\
(100: 11: 11: 27)\end{array}$ & 0.6285 \\
\hline 4 & Tannins & Butanol: acetic acid: Distilled water $(4: 1: 5)$ & 0.3538 \\
\hline 5 & Phenol & Chloroform: distilled water $(27: 3)$ & 0.6769 \\
\hline
\end{tabular}




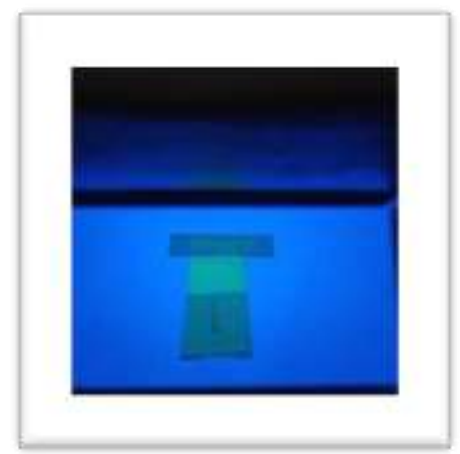

Fig. 2a.Alkaloids

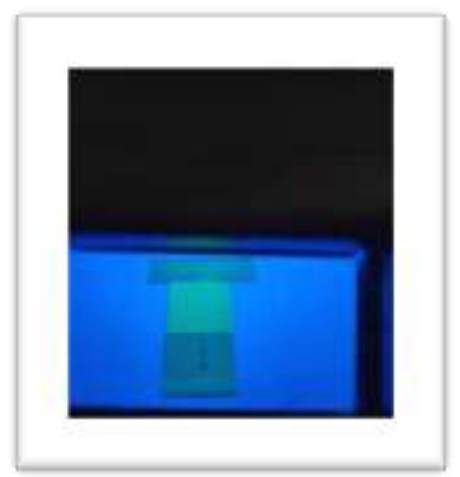

Fig. 2d. Tannins

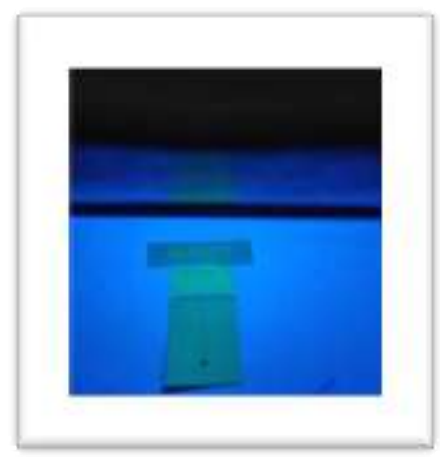

Fig. 2b.Glycoside

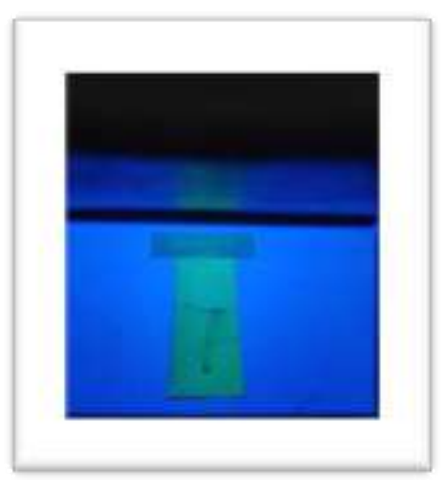

Fig. 2e.Phenol

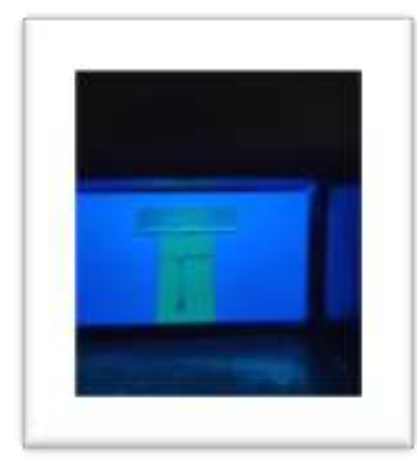

Fig. 2c. Flavonoids

\section{Anti-bacterial activity of Solanum surattense fruit extracts}

\section{A. The disk diffusion method}

Antibacterial activity of hydroalcoholic extracts of Solanum surattense fruit $(1 \mathrm{mg} / \mathrm{ml})$ was employed by disc diffusion method toevaluate their bacteriostatic and bactericidal properties. Effect of the effective plant extract was reported inTable 3 and illustrated in Fig. 3aand 3b. Efficacy data analysis showed that hydroalcoholic extracts of fruit of Solanum surattense $(1 \mathrm{mg} / \mathrm{ml})$ inhibited the growth of Staphylococcus aureus, Bacillus subtilis, Escherichia coli and Salmonella typhi with mean diameters of inhibition zones being 24, 25, 28 and $30 \mathrm{~mm}$ respectively.

Table 3: Anti-bacterial activity of Solanum surattense fruit extracts

\begin{tabular}{|l|l|l|l|}
\hline \multirow{2}{*}{ Type of Bacterial strain } & \multicolumn{2}{|l|}{ Inhibition zones $\mathbf{( m m})$} \\
\cline { 2 - 4 } & $\begin{array}{l}\text { Standard } \\
\text { Ciprofloxacin } \mathbf{( 3 0} \boldsymbol{\mu g})\end{array}$ & $\begin{array}{l}\text { Solanum } \\
\text { fruit extracts } \mathbf{( 1} \mathbf{~ m g} / \mathbf{m l} \mathbf{)})\end{array}$ & Solvent \\
\hline Staphylococcus aureus & 30 & 24 & 3 \\
\hline Bacillus subtilis & 31 & 25 & 2 \\
\hline Escherichia coli & 30 & 28 & 4 \\
\hline Salmonella typhi & 33 & 30 & 2 \\
\hline
\end{tabular}




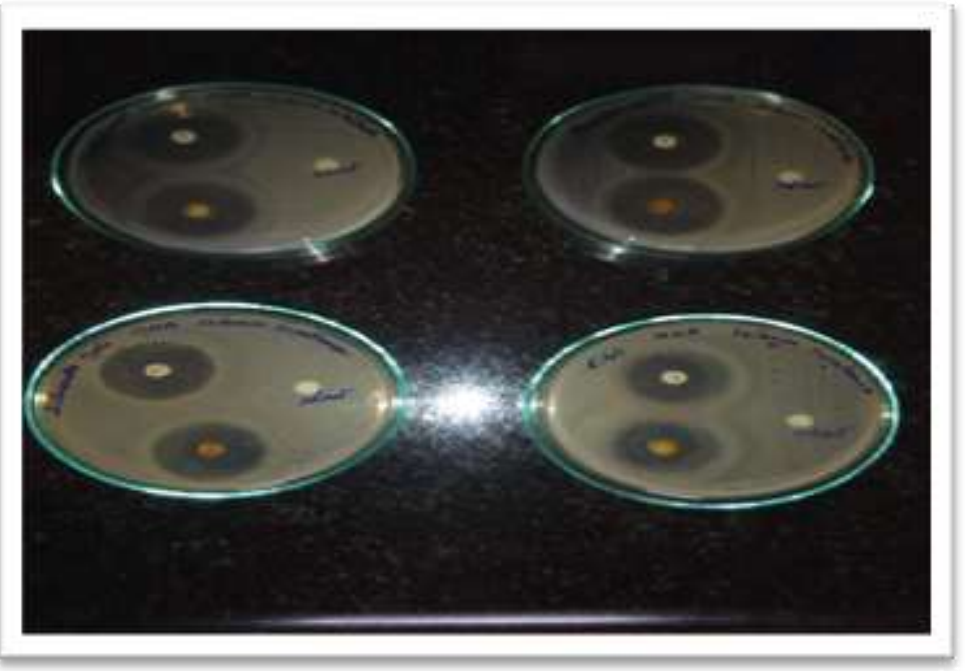

Fig.3a. Growth inhibition caused by Solanum surattense fruit extract

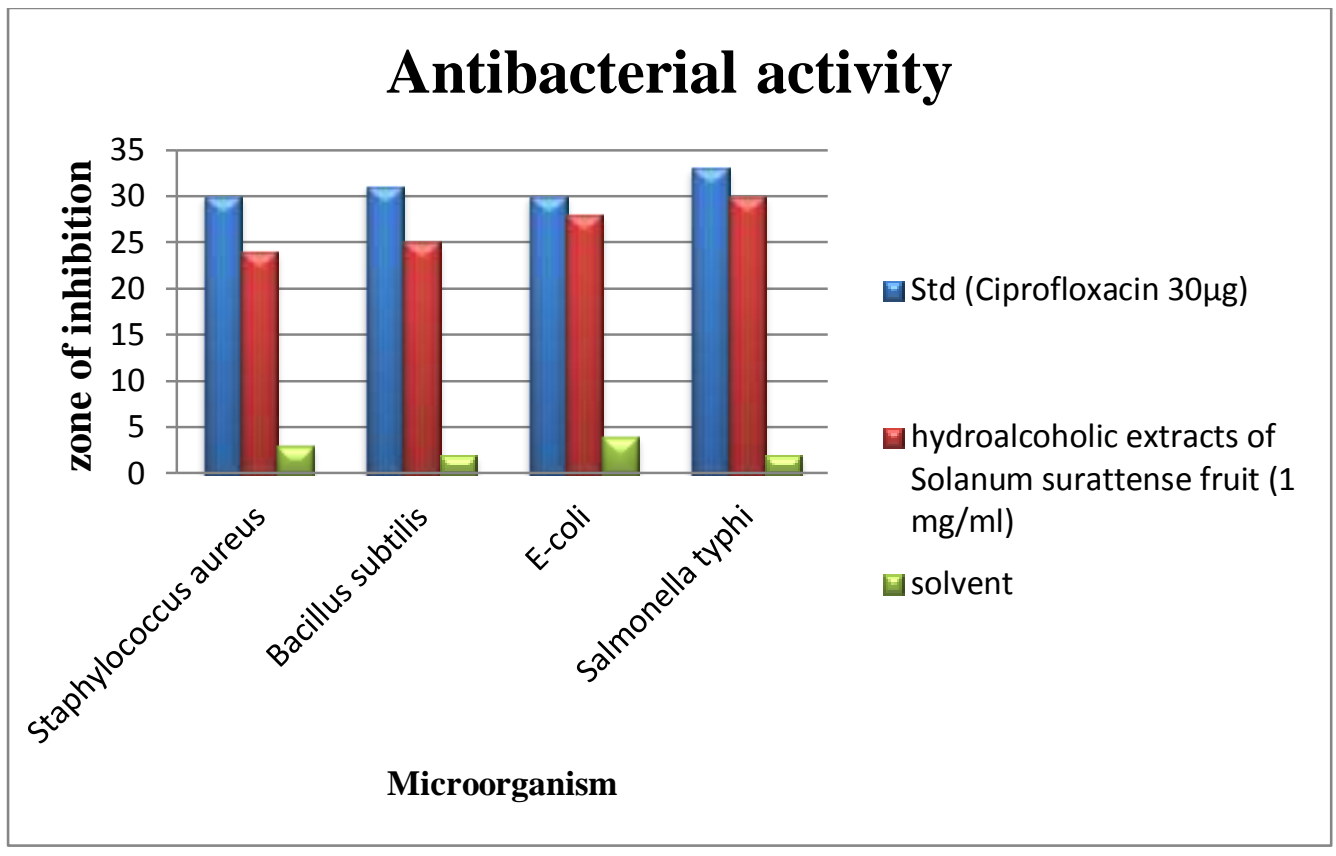

Fig.3b.Growth inhibition caused by Solanumsurattense fruit extracts

Determination of MIC and MBC values

Minimum inhibitory concentration and minimum bactericidal concentration value have been determined with Solanum surattense fruit extracts ( $1 \mathrm{mg} / \mathrm{ml}$ )(Fig. 4). MIC and MBC value of 0.062 and 0.25 $\mathrm{mg} / \mathrm{ml}, 0.062$ and $0.25 \mathrm{mg} / \mathrm{ml}, 0.312$ and $0.125 \mathrm{mg} / \mathrm{ml}$ and 0.156 and $0.0312 \mathrm{mg} / \mathrm{ml}$ were recorded against Staphylococcus aureus, Bacillus subtilis, Escherichia coli and Salmonella typhi respectively (Table 4). 


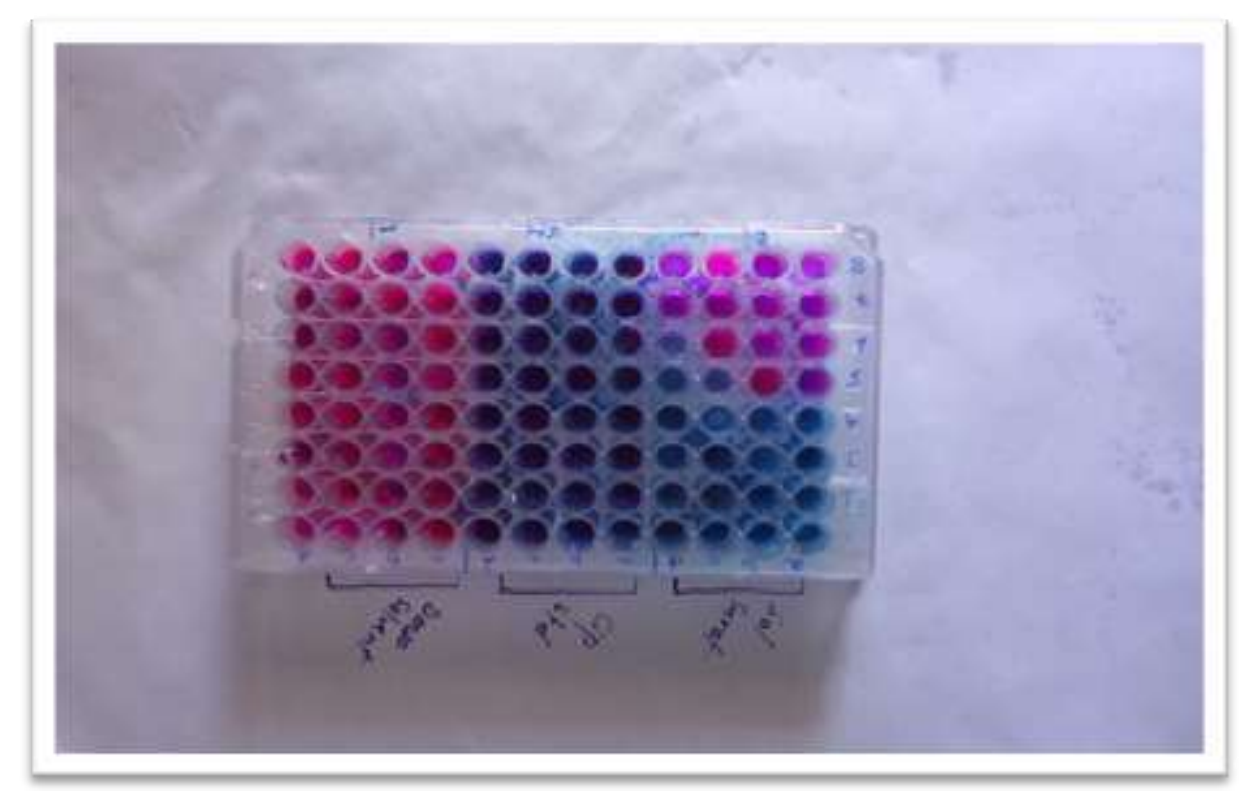

Fig 4: Determination of the MIC values of Solanum surattense fruit extract

Table 4: MIC and MBC values for the Solanum surattense fruit extracts

\begin{tabular}{|l|l|l|}
\hline $\begin{array}{l}\text { Type of Bacterial } \\
\text { strain }\end{array}$ & $\begin{array}{l}\text { Minimum Inhibitory } \\
\text { Concentration (MIC) }\end{array}$ & $\begin{array}{l}\text { Minimum bactericidal } \\
\text { concentration (MBC) }\end{array}$ \\
\hline Staphylococcus aureus & $0.062 \mathrm{mg} / \mathrm{ml}$ & $0.25 \mathrm{mg} / \mathrm{ml}$ \\
\hline Bacillus subtilis & $0.062 \mathrm{mg} / \mathrm{ml}$ & $0.25 \mathrm{mg} / \mathrm{ml}$ \\
\hline Escherichia coli & $0.0312 \mathrm{mg} / \mathrm{ml}$ & $0.125 \mathrm{mg} / \mathrm{ml}$ \\
\hline Salmonella typhi & $0.0156 \mathrm{mg} / \mathrm{ml}$ & $0.0312 \mathrm{mg} / \mathrm{ml}$ \\
\hline
\end{tabular}

\section{Discussion}

Research for new antibacterial agents has become a very important endeavour, especially in recent times, considering the escalating levels of antibiotic resistance among pathogenic bacteria. One of the efforts in this research is focused on the use of medicinal plants, which are widely available resources, less if no side effects, less expensive and have shown antimicrobial properties ${ }^{18}$. Preliminary phytochemical analyses revealed that hydroalcoholic extract of Solanum surattense fruit containing alkaloids, flavonoids, phenol, saponins, terpenoids, glycosides, sterols, proteins and tannins. These bioactivecompounds have been reported to be used by plants for protectionagainst bacterial and are responsible for antimicrobial activity ${ }^{19,20,21}$. Thin layer chromatography is usually done for a better identification of the bioactive compounds. In the present study the TLC profiling of plant extract again revealed the presence of different metabolites such as alkaloids, flavonoids, glycosides, phenols and tannins. Agar well diffusion method and MIC value has been used by many investigators to find out the antimicrobial activity of the test compounds ${ }^{22,23,24}$. Results of antimicrobial activity of the hydroalcoholic extracts of Solanum surattense fruit can suggested that Staphylococcus aureus, Bacillus subtilis, Escherichia coli and Salmonella typhiwere most susceptible strains to the extract and showed strong antibacterial activity. Hence, experiments were conducted to determine their minimal inhibitory concentration (MIC) and minimal bactericidal concentration (MBC) against the most susceptible bacterial strains. In the present study the MIC value of the active plant extracts obtained in this study were lower than the MBC values suggesting that the plant extracts were bacteriostatic at lower concentration but bactericidal at higher concentration. 


\section{Conclusion}

The result of this study showed that hydroalcoholic extracts of Solanum surattense fruits have potential antimicrobial components that may be definitely used as a therapy against various disease by the pharmaceutical industries. However, further studies areneeded, including toxicity evaluation and purification of active antibacterial constituents from Solanum surattense extracts looking toward a pharmaceuticaluse.

\section{Acknowledgement}

The authors express their deep sense of gratitude to Prof. Dr. D. Babu Ananth Principal, E.G.S. Pillay College of Pharmacy, Tamil Nadu and India for providing all the supports and encouragement in conducting the research work.

\section{References}

1. Al-Essa M.A, Al-Mehaidib A, Al-Gain S. Parental awareness of liver disease among children in Saudi Arabia. Ann. Saudi Med. 1998;18 (1):79-81.

2. Cowan MM. Plant products as antimicrobial agents. ClinMicrobiol Rev 1999; 12(4): 564-82.

3. BorgesA.J, Saavedra M, Simoes, M. Insights on antimicrobial resistance,biofilms and the use of phytochemicals as new antimicrobial agents. Curr.Med. Chem. 2015;22 (21):2590-2614.

4. Sharma A. Antibacterial activity of ethanolic extracts of some arid zone plants. Int. J. of Pharm.Tech. Res. 2011; 3(1):283-286.

5. Gyles C. The growing problem of antimicrobial resistance. Can Vet J 2011; 52(8): 817-20.

6. Kim H, Park SW, Park JM, Moon KH, Lee CK. Screening and isolation of antibiotic resistance inhibitors from herb material Resistant Inhibition of 21 Korean plants. Nat. Prod. Sci. 1995; 1: 50 - 54.

7. Alagesaboopathi C. Antimicrobial Potential and Phytochemical Screening of Andrographis affinis Nees, An Endemic Medicinal Plant from India. Int. J. of Pharma. and Pharmaceutical Sci. 2011; 3 (2): 157- 159.

8. Mandal S.M, Roy A, Ghosh A.K, Hazra T.K, BasakA, FrancoO.L. Challenges and future prospects of antibiotic therapy: from peptides to phagesutilization. Front.Pharmacol. 2014; 5 (5): 1-12.

9. Nadkarani AK. Indian Materia Medica1. Bombay: Popular Book Depot; 1954; 3: 1153-1158.

10. http://vikaspedia.in/agriculture/crop-production/package-of-practices/medicinal-and-aromaticplants/solanum-surattense-1

11. Kar DM, Maharana L, Pattnaik S, Dash GK. Studies on hypoglycaemic activity of Solanum xannthocarpum Schard. And Wendl. fruit extract in rats. J Ethnopharmacol. 2006;108(2):251-256.

12. Gupta S, Mal M, Bhattacharya P. Evaluation of hypoglycemia potential of Solanum xanthocarpum (Solanaceae) fruits in normal and streptozotocin induced diabetic rats. Eur Bull Drug Res. 2005; 13:5155 .

13. Sridevi M, Senthil S, Pugalendi KV. Antihyperglycemic effect of Solanum surattense leaf-extract in streptozotocin induced diabetic rats. J Pharmacol Toxicol. 2007;2(7):621-629.

14. HarborneA.J. Phytochemical methods A Guide to Modern Techniques of Plant Analysis. 1998; $3{ }^{\text {rd } E d n ., ~}$ Springer, New York, USA

15. Harborne JB. Phytochemical methods: A Guide to Modern techniques of plants Analysis. 1998; Chapman and Hall London,UK.

16. MostafaA.A. Antimicrobial activity of some plant extracts against bacterial strains causing food poisoning diseases; Saudi Journal of Biological Sciences. 2018; 25: 361-366.

17. Sarker S.D.Microtitre plate-based antibacterial assay incorporating resazurin as an indicator of cell growth, and its application in the in vitro antibacterial screening of phytochemicals/ Methods. 2007; 42: 321-324.

18. Rubens DM, Constantin OO, Moevi AA, Nathalie GK, Daouda T. Anti-Staphylococcus aureus activity of the aqueous extract and hexanic fraction of Thonningia sanguinea (Cote ivoire). Int $\mathrm{J}$ Pharmacogn Phytochem Res 2015; 7(2): 301-6.

19. Sukandar EY, Sunderam N, Fidrianny I. Activity of Kaempferia pandurata (Roxb.) rhizome ethanol extract against MRSA, MRCNS, MSSA, Bacillus subtilis and Salmonella typhi. Pak J Biol Sci. 2014; 17(1): 49-55. 
20. Najafi S. Phytochemical screening and antibacterial activity of leaf extract of Ziziphus mauritiana Lam. Int Res J Appl Basic Sci. 2013; 4(11): 3274-6.

21. Kumar S, Pandey AK. Chemistry and biological activities of flavonoids: an overview. Scientific World Journal. 2013; 2013: 162750.

22. Arora DS, Kaur GJ. Antibacterial activity of some Indian medicinal plants. J. Nat. Med. 2007; 61:313317.

23. GurudeebanS, Rajamanickam E, Ramanathan T, Satyavani K. Antimicrobial activity Of Citrulluscolocynthis in Gulf of Mannar. Int. J. of Curr. Res. 2010; 2: 078-081.

24. Pavithra PS, Janani VS, Charumathi KH, Indumathy R, Potala S, Verma RS. Antibacterial activity of the plant used in Indian herbal medicine. Int. J. of green pharma. 2010; 10: 22-28. 